A MUSLIM BIBLIOPHILE IN SOVIET MOSCOW: THE LIBRARY OF IMAM AHMETZYAN MUSTAFIN

Islam Zaripov islamzarif@gmail.com

Marat Safarov safarov84@mail.ru

\author{
Islam Zaripov \\ Ph.D. in History, Deputy Director of the \\ Moscow Islamic College \\ Marat Safarov \\ Ph.D. in Pedagogy, Associate Professor \\ of the Department of Humanities and \\ Social Sciences of the Institute of \\ Economics and Management in Industry
}

The article summarizes some material on the study of the imam-khatyb of Moscow Cathedral Mosque Abmetzyan Mustafin's library (19021986). The analysis of Mustafin's book collection is determined not only by purely bookish interest, but also by the intention to study more thoroughly the daily life of a prominent Muslim religious figure of the Soviet times, bis reading interests, bis attitude to the book culture, his approach for collecting religious and reference literature. The chronological scope of the collection includes books and manuscripts up to the late eighteenth century and until the 1970s and early 1980s. Mustafin's library contains books in Arabic, Turkish, Tatar and Farsi. It also covers various spheres of Muslim theology - Qur'anic exegetics (tafsir), prophetic traditions (hadith), the biographies of the Prophet and his companions (sira), bistory (tarib), religious law and its methodology (fiqh wa usul al-fiqh), morality (akblaq), mysticism (tasawwuf) and philosophy (falsafa). Dictionaries occupy a significant place, as well as various editions from the 1960-80s (for example, Qur'an commentaries) brought from foreign trips or received as a gift from foreign guests. Of interest are Tasbkent editions of the Qur'an - the fact that expands the idea of Islamic institutions existence in the USSR. We also tried to keep track of the marginal notes on the books.

Keywords: Islam in the USSR, Moscow Cathedral Mosque, library, tafsirs, dictionaries, facsimile. 


\section{МУСУЛЬМАНСКИЙ КНИЖНИК СОВЕТСКОЙ МОСКВЫ: БИБЛИОТЕКА ИМАМА АХМЕТЗЯНА МУСТАФИНА}

\author{
Ислам Зарипов \\ islamzarif@gmail.com \\ Марат Сафаров \\ safarov84@mail.ru
}

DOI: http://dx.doi.org/10.24848/islmlg.07.2.06

В статье обобщень материаль по изучению библиотеки многолетнего имам-хатььба Московской Соборной мечети Ахметзяна Мустафина (1902-1986). Анализ книжного собрания Мустафина обусловлен не только сугубо археографическими задачами, но и стремлением более полно изучить повседневную Ислам Амирович тизнь бидного мусульманского религиозного деятеля советскоЗарипов го Времени - его читательские интересьь, отношение к книге,

Кандидат исторических наук, заместитель директора Московского исламского колиеджа по научной работе

\section{Марат Абясович Сафаров}

Кандидат педагогических наук, доцент кафедрь общегуманитарньюх и сочиальньхх дисиилхин Института экономики и управления В промьпиленности механизмь собирания религиозной и справочной литературь. Хронологические рамки собрания включают книги и рукописи, датированнье кониом XVIII века, и вплоть до начала 1980-х 22. Библиотека А. Мустафина представлена литературой на арабском, туречком, татарском и персидском язьках и охватььвает различнье сферь мусульманского богословия - кораническую экзегетику (тафсир), сьященнье предания (хадис), жития Пророка и его сподвижников (сира), историю (тарих), исламское право и его методологию (фикх ва усул ал-фикх), нравственность (ахлак), мистииизм (тасаввуф) и философию (фалсафа). Большое место занимают словари, а также привезеннье из зарубежньх поездок или полученнье в подарок от иностранных гостей различнье издания 1960-80-х г2. (например, тафсирь). Особьй интерес для расширения пред-

ставлений о существовании исламских институций в СССР представляют уникальнье малотиражнье ташкентские издания СААУМ. При изучении состава собрания вьявлень владельческие пометки.

Ключевые слова: ислам В СССР, Московская Соборная мечеть, библиотека, тафсирь, словари, факсимиле.

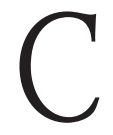

реди нескольких цичностей, оказавших большое влияние на историю ислама в СССР, особое место занимает Ахметзян Мустафин (1902-1986)‥ В 1956-1986 гг. он явцялся имам-хатыбом Московской Соборной мечети. Ахметзян Мустафин принадлежит к тем фигурам, без которых прошиое российских мусульман, по сушеству, нельзя и представить. Роль этой цичности и значение ее Аля истории ислама в России особенно значимы еще и потому, что свою многолетнюю активную религиозную деятельность Мустафину довелось вести в тяжелых условиях антирелигиозных кампаний

1. В 2017 году в издательском доме «Медина» вышиа монография, посвященная Ахметзяну Мустафину. Зарипов И.А., Сафаров М.А. Ахметзян Мустафин: из истории ислама в СССР. - Москва: ИА «Медина», 2017. - 404 с. 
и атеистической пропаганды. Получивший глубокое образование в казанском медресе «Мухаммадия» выдающегося религиозного деятемя Галимджана Баруди, обладавший колоссальным опытом организаџии религиозной жизни, он являлся оАним из веАущих имамов советской эпохи, которые передали дореволюџионные традиџии джадидской богословской школы новому поколению мусульманского Ауховенства, возглавившему умму в постсоветский период.

Неслучайно в середине 1970-х гг. А. Мустафин в течение года исполнял обязанности председателя Ауховного управления мусульман Европейской части СССР и Сибири. Он быц одним из весьма ограниченного круга религиозных деятелей своего времени, кто был допущен властями к межАународной деятельности: встречался с зарубежными государственными и духовными мидерами, такими как Гамаль Абдель Насер, МохаммеА Реза Пехлеви, Ахмед Сукарно, Муаммар КадАафи, король Марокко Хасан II, президент Сирии Шукри ал-Куатли и многие другие. Эти встречи становицись событиями в жизни московских мусульман, способствоваци повышению статуса Московской Соборной мечети как важного религиозного центра нашей страны².

Ахметзян Мустафин в значительной мере повциял на сохранение у московских мусульман в советское время приверженности своим духовным корням. Он также сыграл особую роль в защите Московской Соборной мечети от намечавшегося в конце 1970-х гг. сноса. Твердый характер Ахметзяна Мустафина, его богатейший жизненный опыт, умение находить компромиссы, детацьное понимание особенностей своего времени - все это во многом помогло московской мусульманской общине сохраниться в трудных усцовиях господства атеистической идеологии и обрести возрождение в новой России. Скончался Ахметзян Мустафин в ноябре 1986 г., на заре наступавших в государстве перемен, в частности по отношению к религии.

Особое место в жизни Ахметзяна Мустафина как ученого и религиозного деятеля занимали книги. По существу, в советской Москве Мустафин представлял собой тип восточного интелмектуала-книжника. Передавая нам часть его библиотеки, племянница имама Хабиба Якубова (1934 г.) вспоминала, как в последние дни своей жизни он напутствовац ее в отношении книг, говоря, что именно они составцяци основу всей его жизни.

Еще будучи шакирдом, он старался как можно больше читать, используя мюбую возможность дмя этого. Вспоминая годы учебы у известного татарского просветитеця ишана Хамидумиы Альмушева (1855-1929) в селе Петряксы Симбирской губернии, он отмечает уникальную возможность пользоваться его богатейшей библиотекой, в которой храницись фундаментальные труды классиков мусульманского богословия ${ }^{3}$. В своих воспоминаниях ${ }^{4}$ А. Мустафин пишет: «Моя первая встреча с уважаемым и достопочтимым устазом Хамидулмой-хазратом произошла осенью 1926 года в его доме в селе Петряксы. На этой встрече я попросиц уважаемого устаза, если есть такая возможность, разрешить мне остаться некоторое время в Петряксах Аця получения знаний. Уважаемый устаз с радостью согласицся. С этого дня я стац черпать знания

2. Подробнее о международном значении Московской Соборной мечети, обретении ею представительских функций см.: Зарипов, Сафаров, 2017, с. 96-98.

3. Об Альмушеве подробнее: Алимова, Сенюткина, Мухетдинов, 2007, с. 18-19.

4. Краткие воспоминания А. Мустафина на татарском языке, хранящиеся у потомков имама, частично опубликованы в Зарипов, Сафаров, 2017. 
у уважаемого устаза. Около трех $е$ я я обучался у уважаемого устаза комментарию Корана (тафсир), Священному Преданию (хадис), практическому богословию (фикх), Аогматике (акаид) и другим наукам. В 1928 году уважаемый устаз выдац мне написанное собственной рукой в известной среди ученых форме свидетельство (иджазатнаме). Устаз Хамидумла-хазрат прекрасным образом разъяснял уроки, приводя, когда это было необходимо, примеры. Иногда он рассказывал о годах своей учебы в Маска$\mathrm{pe}^{5}$, Бухаре и лучезарной Медине, знакомя нас с событиями того времени. В это время у хазрата обучались и Аругие студенты. Я же особенно благодарен своему устазу, потому что он разрешиц мне пользоваться своей богатой библиотекой. Помимо уроков, я получиц возможность читать находящиеся в этой библиотеке книги таких великих ученых, как Ибн Таймийа, Ибн ал-Кайим и ал-Газали, смог познакомиться с комментариями к сводам священных преданий имама Бухари и Муслима, а также другими ценными и значимыми исламскими произведениями. Аосточтимый устаз был высоконравственным и чрезвычайно терпеливым человеком. Как во время уроков, так и в другое время он с радостью отвечац на обращенные к нему вопросы и считал служение на пути знаний своим Аолгом» ${ }^{6}$.

Но жизненные перипетии, вызванные антирелигиозной политикой советского госуАарства, не позволици Мустафину начать собирать собственную библиотеку в молодости. Такую возможность он получиц мишь став официальным имам-хатыбом Московской Соборной мечети в 1956 году.

ОАнако найти мусульманскую религиозную цитературу в советской Москве было непростым делом. Поэтому основу его собрания составици дореволюционные издания и рукописи, которые передавались имаму престарелыми прихожанами и их Аетьми.

Уничтожение советской властью всеобщего мусульманского религиозного образования и, в большой степени, перевод письменности татарского языка с арабской графики на матиницу, а затем кириццицу кишици новые поколения возможности читать митературу прошлых столетий. В частной переписке пожилые московские татары использоваци арабицу (встречались и случаи подписей арабицей офиџиальных заявлений прихожан мечети), однако знание не воспроизводицось в новых поколениях. Но многовековая история татарской арабографической книги и ее особое место в наџионацьной культуре отразицись в жизни почти каждой семьи многочисленными собраниями рукописей и изданий, которые осознававшие их ненужность собственным отпрыскам старики и сами дети после смерти родителей относили имаму в мечеть в надежде, что здесь они будут сохранены и востребованы. Здесь сказывалось и сакральное отношение татар к арабографическим текстам, особенно распространившееся в советское время (когда содержание текста уже не было понятно большинству, но сохранялось убеждение в «святости» подобного изАания ици рукописи).

Таким образом к Мустафину, например, поступим изданный в 1909 г. в казанской типографии братьев Каримовых двухтомный сборник хадисов имама ас-Суйути «А Ажами“ ас-сагир», на форзаце одного из томов которого написано: «Из библиотеки имам-хатыба Мухаммад Вафы Сабирова дер. Петряксы Курмышского уезда Симбир-

5. Маскара (тат. Мәчкәрә) - село в нынешнем Кукморском районе Татарстана.

6. Из кичного архива авторов. Перевод с татарского. 
ской губернии» книга была у Исхака абзый Туктарова из Петрякс, после смерти которого 6 декабря 1971 г. мне ее передац Хамза-кардаш в Московской мечети».

Быми в его библиотеке и книги с мичными подписями и именными печатями военного ахуна Саидбурханова (ал-Газали «Мукашафат ал-кулуб», 1323 г.х.), а также уроженца деревни Антяровка Уразовской волости Сергачского уезда Нижегородской губернии Мустафы Бедретдинова («Сийар ан-наби», 1907 г.).

На рукописи нескольких частей одной из самых популярных ханафитских книг по мусульманскому праву «Хидая» стоит сургучная печать московского ахуна Рафика Агеева (ум. 1873) и его мичные автографыв. Как гласит одна из надписей на тыльной стороне обложки, эта книга была приобретена им в 1843 г. за 20 рублей у наследника дамулмы Сайфульмулюка сына Асхаба. Интересно отметить, что одна из надписей на этой книге посвящена краткому описанию французской оккупации Москвы 1812 г. и произошедшего в это время пожара, а также участию мусульман в этой войне. ОАнако более подробное описание этой книги, как и ряда других из собрания А. Мустафина, требует отдельных публикаций.

Вероятнее всего, точно таким же путем к нему поступици и другие имеющиеся в его библиотеке дореволюџионные книги и рукописи. Среди них можно отметить печатную книгу Уиожения законов Екатерины II на татарском языке 1775 г., две рукописи «Казихан китабы» на арабском, одна их которых датируется 1085 годом по хиджре, казанские издания «Алты бармак китабы» (1884 и 1910 гг.), «Ахыр заман» (1907 г.), «ТарАжамациахадис мунтахаба» (1912 г.), оренбургское издание книги А. Ажафара «Сөәл вә жаваплы хөснел-бәдә» (1909 г.) и османские издания Ахмеда Мидхата «Низаме гыйлем вә дин. Ислам вә голүм» (1313 и 1315 г.х.) и «Хакыйкый бер мөселман Ааимән мөкәммәл бер инсан» (1328 г.х.).

Отчасти к этой же категории можно отнести и единственную книгу с печатью 2-го мусульманского приходского совета города Москвы, т.е. Аореволющионной библиотеки Московской Соборной мечети, «Ас-сирадж ал-мунир шарх ал-джами“ ас-сагир» (1403 г.х.). К сожалению, Аореволюционное собрание библиотеки мечети не сохраницось до наших дней, а книги с ее знаками сегодня можно встретить как в частных колмекциях, так и в фондах РГБ.

Второй фонд библиотеки А. Мустафина составляет немногочисленная мусульманская митература, изданная в СССР. Эти уникальные малотиражные ташкентские издания 1970-80-х гг. преподносились в качестве подарков зарубежным гостям и были недоступны абсолютному большинству советских мусульман. Из них у московского имама в пользовании находилась книга ал-Бухари «Китаб аАаб ац-муфраА» (1970 г.), книга муфтия СААУМ Зияутдин-хана ибн Ишан Бабахана «Ал-ислам ва- -муслимун фи-ц-билад ас-суфитийа»

7. Здесь и далее перевод авторов с татарского и арабского.

Вафа Сабиров (1885-1966) был зятем Хамидулы Альмушева, образование получил, как и Мустафин, в казанском медресе «Мухаммадия» у Галимджана Баруди. С 1910 г. Вафа Сабиров являлся имамом в селе Петряксы. В 1927 г. его жену, которая была учителем в местной школе, должны были выселить из Петрякс в село Пица, поскольку проживание в одном населенном пункте имама и его родственников - советских учителей было невозможно. С целью избежать выселения семьи Вафа Сабиров принял тяжелое решение и покинул пост имама. В этом его поддержал и Хамидулма Альмушев. ОАнако за этот поступок в течение долгих иет Вафа Сабиров, его жена и дети подвергались нападкам и оскорблениям со стороны односельчан. Кроме того, Вафе Сабирову как бывшему «представителю духовенства» в 1930-е гг. вполне мог угрожать арест, в связи с чем он часто уезжал в Москву, где жили два его сына и другие близкие родственники. Позднее он работал в колхозе пчеловодом. Подробнее: Сабиров, 2005.

8. Более подробно о библиотеке Агеевых см.: Зайцев, 2010. 
(1400 г.х.) и репринтное издание рукописи ат-Тирмизи «Аш-шама'ил ан-набавийа» (1400 г.х.), на форзаце которого рукой А. Мустафина написано: «12 сентября 1980 г. милаАи - 1400 г.х. я участвовац в конференции, посвященной священному переселению (хиАжра) Пророка, в городе Ташкенте, и нам вручили это как подарок участникам конференции. Имам-хатыб Ахметзян Мустафа Иукман аш-Шубили, затем Маскави».

Имелись у Мустафина и изданные в СССР многочисленные арабско-, турецкои персидско-русские словари, а также рял работ советских арабистов, среди которых можно отметить труд академика И.Ю. Крачковского по истории арабской цитературы «Аирасат фи тарих ац-адаб ац-'араби» (Москва: «Наука», 1965).

Еще одним источником формирования библиотеки московского имама стали подарки зарубежных единоверџев, которые в 1960-80-е гг. посещали мечеть в столице СССР. На многих из таких книг А. Мустафин собственноручно подписывац имя дарителя, дату и обстоятельства преподнесения подарка.

Так, например, на форзаце книги Мухаммада Фарида Ваджди «Ал-мусхаф ацмуфассар» (1377 г.х.) его рукой арабиџей на татарском было подписано: «Этот комментарий к Корану (тафсир) Мухаммада Фарида Ваджди был передан нам 16 ноября 1968 г. египтянином Фатхи Фатхулцахом Ахмадом на пятничной молитве. Ахметзян».

Похожая надпись украшает и подарок офиџиальной амжирской демегаџии - книгу ац-Ажазаири «Китаб ац-мавакиф фи-т-тасаввуф ва- -ва'з ва- $\Lambda$-иршаА», в которой говорится: «О передаче этой книги в качестве подарка от прибывшего из А^жира Аабни Вафд было объявлено в пятницу 13 августа 1971 г., и на следующий день 14-го во время полуденной молитвы ее передали нам. В составе этой делегации был министр по делам ислама Алжира Мавлуд Касим, который присутствовац на пятничной молитве, во время которой я приветствовац их. Министр Мавцуд Касим поприветствовац мусульман, а после пятничной молитвы в зале приемов мечети нами быц дан обеА. Ахметзян Мустафа».

На трехтомном бейрутском издании 1968 г. книги Кандахмяви «Хаят ас-сахаба» стоит надпись: «Эта книга была подарена группе наших паломников в 1980/1400 г. верховным муфтием Сирии Ахмадом Куфтаро. Получил 1 мухаррама 1401 года хиджры - 9 ноября 1980 г. Ахметджан Мустафа - имам-хатыб Московской мечети»?

Будучи одним из цидеров советского ислама, в эти годы А. Мустафин и сам посещац зарубежные страны, из которых привозиц так мюбимые им книги. Среди них можно отметить уникальный репринт комментария к Корану на татарском языке «Тафсир Ногмани», изданный в 1958 г. в Хельсинки ${ }^{10}$. Он был преподнесен в дар имаму московской мечети во время его посещения татарской мусульманской общины Финцяндии в 1967 г. одним из ее основателей - уроженцем нижегородского села Актуково ИмаАом Ажамалетдином, который подписац книгу: «Очень Аорогому Ахметзяну казыю на память. Хельсинки, 9.10.1967. ИмаА Ажамалетдин». Аалее рукой самого А. Мустафина написано: «В собственности Ахметзяна Мустафина - имам-хатыба Московской Соборной мечети. Передано мне в подарок Аругом Имадом Ажамалетдином во время поездки в ФинАяндию в 1967 г.»11.

9. Ахмад Куфтаро (1915-2004) - многолетний муфтий Сирии; неоднократно посещал СССР.

10. О контактах АУМЕС (и Мустафина в частности) с татаро-мусульманской общиной Финияндии см.: Беляев, Зарипов, Сафаров, 2016.

11. Подробнее об истории татарской общины Финияндии и контактах мусульман СССР со своими единоверцами из Финияндии см.: Бемяев, Зарипов, 2016; Бемяев, Зарипов, Сафаров, 2016. 
Почти все свои книги А. Мустафин подписывац, причем с изменением его статуса как религиозного деятеля можно проследить и эволюџию подписи - с короткой «Ахметзян Мустафа» в 1950 г. (например, на книге «Тарджама мактубат имам Раббани») до «Ахметзян б. Мустафа б. Аукман б. Шах-Ахмад б. Ахмар б. Баязид, деревня АшШубили (Шубино), Сергачский район, Горьковская область, затем город Москва, имамхатыб Московской мечети, чмен Ауховного управления мусульман Европейской части СССР и Сибири» в 1982 г. (на книге «Ал-мураджа'ат абхас Ажадида фи усул ал-мазхаб ва- -амама ам-'амма», Каир, 1979).

Были в его библиотеке и многочисленные казанские и арабские издания Корана и разцичных молитвенников (догалыклар), а также Евангелие (Инджиль) на арабском языке.

Как видно из вышеперечисленных книг, библиотека А. Мустафина представлена митературой на арабском, турецком, татарском и персидском языках и охватывает различные сферы мусульманского богословия - кораническую экзегетику (тафсир), священные предания (хадис), жития Пророка и его сподвижников (сира), историю (тарих), исламское право и его методологию (фикх ва усул ал-фикх), нравственность (ахлак), мистицизм (тасавbуф) и философию (фалсафа). Помимо традиционной суннитской митературы, встречаются в ней и несколько шиитских книг (например, «Ат-такамул фи$\Lambda$-ислам» (Кум), «Ал-имам ас-Садик ва- -мазахиб ал-арба'а» (В 3-х томах. Бейрут, 1981), ас-саййид “Али Хусейн Хомейни «Рух ат-тавхиА” (Тегеран, 1402 г.х.), которые, вероятнее всего, были преподнесены в дар представителями Ирана и Аивана. ОАнако даже в них можно встретить пометки А. Мустафина, которые он делац на полях на арабском и татарском языках.

Необходимо отметить, что такие комментарии присутствуют почти во всех его книгах, что, безусловно, свидетельствует об их внимательном и осознанном чтении, использовании при подготовке к проповеАям, удивительная содержательность которых до сих пор с большой теплотой вспоминается прихожанами.

В то же время в библиотеке отсутствуют отдельные книги, написанные цично А. Мустафиным ици его комлегами-современниками. Единственным искиючением явцяется небольшой блокнот с эмблемой МежАународной исламской конференции, проходившей 1-3 октября 1986 г. в Баку, на нескольких страниџах которого им были сделаны пометки на татарском языке арабицей. Эта конференџия стала послеАней в жизни имама.

После смерти А. Мустафина в ноябре 1986 г. некоторые книги из его собрания были розданы наследниками разным Аюдям, и определить их точное местонахождение в настояшее время не представляется возможным. ОАнако ее большая часть, 66 книг, хранилась у его племянниџы Х. Якубовой, которая в 2016 г. мюбезно передала их одному из авторов статьи. 


\section{БИБЛИОГРАФИЯ}

Алимова Ю., Сенюткина О., Мухетдинов А. (2005). Ислам на Нижегородчине: энџиклопедический словарь. Н. Новгород: Медина.

Беляев Р.Ф., Зарипов И.А. (2016). От Кабула до Тампере: штрихи к научной биографии татарского имама Хабибуррахмана Шакира / / Минарет Ислама. - 2016. - № 1-2 (5-6). C. 24-33.

Беляев Р.Ф., Зарипов И.А., Сафаров М.А. (2016). Контакты татарских религиозных деятемей Финцяндии и СССР в 1920-1980-е гг. Tatarica, № 7. С. 99-108.

Сабиров С.В. (2005). Вафа мулма Сабиров: к 120-летию со дня рождения. Н. Новгород: ИзА-во НИМ «Махинур».

Зарипов И.А., Сафаров М.А. (2017). Ахметзян Мустафин: из истории ислама в СССР. Москва: Медина.

Зайџев И.В. (2010). К истории бибциотеки московских имамов Агеевых. PAX ISLAMICA, № 1 (4). С. 43-59.

\section{REFERENCES}

Alimova, Yu., Senyutkina, O., Mukhetdinov, D. (2005). Islam in Nizhny Novgorod: encyclopedic dictionary. N. Novgorod: Medina (in Russian).

Belyaev, R.F., Zaripov, I.A. (2016). From Kabul to Tampere: details on Tatar imam Habiburrahman Shakir academic bio. Minaret Islama, № 1-2 (5-6), 24-33 (in Russian and English).

Belyaev, R.F., Zaripov, I.A., Safarov, M.A. (2016). Contact of Tatar religious figures of Finland and the USSR in 1920-1980s. Tatarika, № 7, 99-108 (in Russian).

Sabirov, S. (2005). Vafa Mulla Sabirov: to the 120th anniversary of his birth. N. Novgorod: Izd-vo MIM Makhinur (in Russian).

Zaripov, I.A., Safarov, M.A. (2017). Ahmetzyan Mustafin: from the history of Islam in the USSR. Moscow: Medina (in Russian).

Zaytsev, I.V. (2010) The history of the library of the Moscow imams Ageev. PAX ISLAMICA. № 1 (4), 43-59 (in Russian). 